\title{
果実野菜に残留する農薬の除去に関する研究*1
}

\author{
(その 1) トマトに残留するボルドーの洗浄条件の検討
}

(昭和 51 年 2 月 20 日受理)

$$
\text { 毛利 善 一² 田村順一*2 }
$$

\section{Studies on Removal of Residual Pesticides from Fruits and Vegetables by Washing}

\author{
Part. 1 A Study on Removal of Residual Bordeaux Used \\ to Tomatoes in Laboratory

\section{Zenichi MōRI and Junichi TAMURA}

(Research Laboratories, Kao Soap Company: 1334, Minatoyakushubata, Wakayama)

For the purpose of finding a method for optimization of removal effect on the residual Bordeaux from tomato, an investigation has been made by use of tomato sprayed with Bordeaux in a laboratory.

It was found that the combined use of sugar fatty acid ester and potassium pyrophosphate exhibited good detergency to remove the residual Bordeaux on tomato.

Using this combined detergent, it was also recognized that almost complete removal of the residual Bordeaux was achieved through the following conditions: more than $0.2 \%$ of detergent concentration, over 2 minutes washing, above $25^{\circ} \mathrm{C}$ as washing temperature, and stirring of washing solutions with above 50 r.p.m.

(Received February 20, 1976)

\begin{abstract}
緒言
果実・野菜をはじめとする食品中の農薬の残留が，食 品衛生上大きな問題となっており, 残留基準值が設定さ れている1が，すべての食品，農薬が網羅されておら ず，このため，適正な農薬の使用方法が必要とされる 他，より完全な農薬除去技術が求められている。これま でに, 残留農薬の洗浄除去性について, 川城ら ${ }^{2)}$, 小野 $\square^{3)}$, 小谷ら ${ }^{4)}$, 出浦 ${ }^{5)}$ は, 中性洗剤が効果があることを 報告している. また, リンゴについては末永ら゙), 久保 田 $^{7)}$, 飯島 ${ }^{8)}$, 山沢 $5^{9)}$ が, トマトについては足立ら ${ }^{10)}$

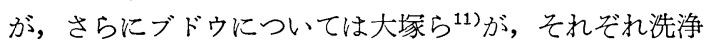
方法, 条件について恰討しており, 中性洗剤の利用につ いても述べている.
\end{abstract}

\footnotetext{
*1 界面活性剂の食品への利用に関する研究 (第2 報). 第 1 報を，毛利，西沢，莫見：栄養と食糧， 28,263 (1975) とする.

*2 花王石䲓 (株) 和歌山研究所: 和歌山市湊薬種畑 1334
}

著者らは, 中性洗剂とは別の角度から安全性も考慮し て, 各成分が食品添加物から構成された洗浄剂の効果を 確認するために, まず第 1 段階として, 試料として加工 時の洗浄が特に重要とされているトマトを選び，トマト に最も多く使用されているボルドーを除去対象として, 最適洗浄条件を検討し, 満足すべき結果を得たので報告 する.

\section{実験方法}

\section{1. 使用機器}

a ）原子吸光分光光度計： Perkin Elmer 社製，503 型

b ）ジャーテスター：(株) 入江製作所製

c）家庭用ミキサー：松下電器産業(株)製

2. 供試試料

a）供試トマト：摘果後 1 日経過したトマトに，4.の 方法により，ボルドーを散布した後，1 日放置したもの を，洗浄用試料として使用した。 


\section{3. 供試薬戍および試薬}

a ）ボルドー：一般に使用頻度の高いといわれる 4-2 式，4-4式の中で，4-4式ボルドーを用いた。すなわち, $4 \mathrm{~g} / \mathrm{L}$ 硫酸銅（和光純薬(株) 製, 試薬特級) 水溶液を, 等量の $4 \mathrm{~g} / \mathrm{L}$ 酸化カルシウム (和光純薬(株)製, 試薬 1 級) 水溶液中にかくはんしつつ添加し, 用時調製 ${ }^{12)}$ した。

b) 展着剂: 日本農薬 (株) 製 (商品名りノ一). 成分, アルキルフェノールポリェチレングリュールェーテル $20 \%$, リグニンスルホン酸塩 $12 \%$ ，水分 $68 \%$

c）界面活性剂：ポリオキシェチレンノニールフェニ ルエーテル (ポリオキシェチレン平均重合度 9 ), 直鎖ア ルキルベンゼンスルホン酸ナトリウム (LAS), アルキル 硫酸ナトリウム（アルキル基鎖長の炭素数 12), ショ糖 ラウリン酸エステル, ショ糖オレイン酸エステル

d）ビルダー：ピロリン酸カリウム，トリポリリン酸 ナトリウム，クエン酸ナトリウム，リンゴ酸ナトリウ ム、 いずれも和光純薬(株)製, 試薬特級

e）中性洗剂: LAS 10\%およびポリオキシェチレン アルキルエーテル硫酸ナトリウム $10 \%$ からなる混合水溶 液を使用した。

その他試薬は，すべて特級品を使用した。

\section{4. ボルドー散布方法}

ジャーテスターのシャフトに皿状のステンレス製容器 をつり下げ，その中に市販トマトを 1 個入れ， $100 \mathrm{rpm}$ で回転させ，あらかじめ調製したボルドーを，家庭用ス プレーを用いて散布した。散布時間はボルドーがしずく となって流れ落るまで行った。 ボルドーは，1日 1 回 3 日間，計 3 回にわたって散布した。なお，展着剤はボル ドーに対し $0.02 \%$ 割合で使用した。

\section{5. トマトの洗净}

ボルドー散布処理したトマトを半切りにし，一方を洗 浄用サンプルとし，もう一方を洗浄しないでそのまま分 析し，トマトに付着しているボルド一量を求めた. 洗浄 条件は，実際にトマト洗浄の際に到達する $\mathrm{pH}$ (4.5) に 調整した一定濃度の洗浄剂水溶液 $800 \mathrm{ml}$ 中に, 半切り したトマト 3 個を同時に入れて, 長さ $7 \mathrm{~cm}$ のプロペラ 羽根を $100 \mathrm{rpm}$ で回転させ， 5 分間 $20 \sim 22^{\circ}$ で洗浄した 後, 同量の水道水で30秒間すすぎ洗いを行った. あらか じめ半切りしたトマトの切りロから銅イオンが吸収され るかどうかを調べたが，全く吸収はされなかった。

洗浄率は下式によって算出した.

洗浄率 $(\%)$

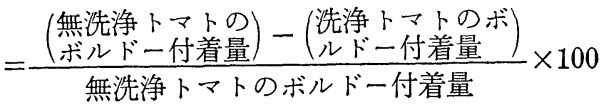

なお，洗浄試験は，3回行い，その平均值を表示した.

\section{6. ボルドー分析方法}

ミキサー (刃はステンレス製) で破粋し，ジュース化 したトマトを $30 \mathrm{~g}$ とり，100 $\mathrm{ml}$ 容量の 3 角フラスコに 入れ, $4 N$ 塩酸 $10 \mathrm{ml}$ を加えた後, 空気冷却管を取り付
Table 1. Distribution of Residual Bordeaux $\mathrm{Cu}$ ) Added to Tomato

\begin{tabular}{c|c|c|c}
\multirow{2}{*}{$\begin{array}{c}\text { No. of } \\
\text { tests }\end{array}$} & \multicolumn{2}{|c|}{$\begin{array}{c}\text { Residues of each piece } \\
\text { cutted in half up and down } \\
(\mathrm{ppm})\end{array}$} & $\begin{array}{c}\text { Total } \\
\text { residues } \\
\text { (ppm) }\end{array}$ \\
\cline { 2 - 4 } & $\mathrm{I}$ & II & \\
\hline 1 & $1.94(52.3)$ & $1.77(47.7)$ & 3.71 \\
2 & $1.67(47.3)$ & $1.86(52.7)$ & 3.53 \\
3 & $1.76(49.4)$ & $1.80(50.6)$ & 3.56 \\
\hline average & $1.79(49.7)$ & $1.81(50.3)$ & 3.60
\end{tabular}

( ), the proportion of $\mathrm{Cu}$ content on residues of each piece cutted in half to total residues $(\%)$

け, 沸騰水中で15分間者沸し, 水冷後, 東洋濾紙 No. 5 Aで，ろ過し，ろ液を原子吸光分光光度計を用いて測定 波長 $324.7 \mathrm{~nm}$ で，銅の測定を行った。銅標準液とし $\tau$, 和光純薬(株)製原子吸光分析用銅 $1000 \mathrm{ppm}$ 水溶液 を希釈して用いた。トマト固有の銅量は $0.3 \sim 0.4 \mathrm{ppm}$ 検出されたが，測定值にはこれらの值を含めた。なお， 銅イオンのロ紙への吸着は，本分析操作では認められな かった.

\section{実験結果および考察}

\section{1.トマト表面におけるボルドーの分析}

洗浄試験を行らに当たり，全体に均一にボルドーが付 着しているか否かをみるために，均等にトマトを縦に 2 分割し，それぞれの付着量を测定した結果を Table 1 に 示した. 2 分した各片の数值は理論值に比べて最大で $\pm 3 \%$ 近い差があり，完全には一致しなかったが，3 個 のトマトについて平均したところ, 綎に 2 分した各片に ほぼ同量付着していることを確認できた。縦に 2 分した 各片が互いに対称でもなく，また完全な球体でもないこ と, スプレーより噴射される霧の粒子の大きさが一定で ないことを考慮した場合, この程度のばらつきは, やむ を得ないと考えられる. 一応, これらの結果より，トマ トを縱に半分に切って, 各々洗浄前と洗浄後の付着量を 求める方法が, ある程度, 妥当であることを確認するこ とができた。

2. ショ糖脂肪酸エステルと他の界面活性剤との洗浄 効果の比較

ショ糖脂肪酸エステルは, 我国で食品添加物として許 可されている界面活性剂の中で唯一の親水性の強いもの で，洗浄剤への利用に関し，幾つかの報文 ${ }^{13) ~ 15)}$ が発表 されている. Table 2 において, 代表的界面活性剂とシ ヨ糖脂肪酸エステルとの洗浄効果を比較したが, 界面活 性剂の種類による洗浄効果の差は見られず, また，水洗 いと比べて界面活性剂の洗浄効果が特に優れているとい った結果は得られなかった. ショ糖脂肪酸エステルは, 洗浄剤としての効果の点では他のものと差がないが，食 
Table 2. Removal Effect of Surface Active Agents on Residual Bordeaux $(\mathrm{Cu})$ Added to Tomato

\begin{tabular}{|c|c|c|c|}
\hline \multirow[b]{2}{*}{$\begin{array}{l}\text { Surface active } \\
\text { agent }^{\text {a) }}\end{array}$} & \multicolumn{2}{|c|}{ Residues } & \multirow[b]{2}{*}{$\begin{array}{c}\text { Removal } \\
\text { efficiency }{ }^{\mathrm{b})} \\
(\%)\end{array}$} \\
\hline & $\begin{array}{c}\text { Before } \\
\text { washing } \\
\text { (ppm) }\end{array}$ & \begin{tabular}{|} 
After \\
washing \\
$(\mathrm{ppm})$
\end{tabular} & \\
\hline $\begin{array}{l}\text { Polyoxyethylene } \\
\text { nonylphenylether }\end{array}$ & 5.00 & 1.83 & 63.4 \\
\hline $\begin{array}{l}\text { Sodium alkylbenzene } \\
\text { sulfonate }\end{array}$ & 5.09 & 1.75 & 65.7 \\
\hline Sodium alkyl sulfate & 5.12 & 1.82 & 64.7 \\
\hline Sugar laurate & 5.05 & 2.01 & 60.1 \\
\hline Water (Control) & 4.98 & 2.27 & 54.3 \\
\hline
\end{tabular}

These values are expressed as the average of three tests.

a) Concentration of surface active agent, $0.1 \%$

b) Removal efficiency (\%) $=\frac{\begin{array}{l}\text { Residues before_Residues after } \\ \text { washing }(\mathrm{ppm})\end{array} \text { - washing }(\mathrm{ppm})}{\text { Residues before washing }(\mathrm{ppm})} \times 100$

Table 3. Removal Effect of Builders on Residual Bordeaux $(\mathrm{Cu})$ Added to Tomato

\begin{tabular}{l|c|c|c}
\multirow{2}{*}{ Builder $^{\mathrm{a})}$} & \multicolumn{2}{|c|}{ Residues } & Removal \\
\cline { 2 - 3 } & $\begin{array}{c}\text { Refore } \\
\text { washing } \\
\text { (ppm) }\end{array}$ & $\begin{array}{c}\text { After } \\
\text { washing } \\
\text { (ppm) }\end{array}$ & $\begin{array}{c}\left.\text { efficiency }{ }^{\mathrm{b}}\right) \\
(\%)\end{array}$ \\
\hline Sodium citrate & 4.14 & 1.06 & 74.3 \\
Sodium malate & 4.20 & 1.24 & 70.5 \\
Potassium & 4.09 & 0.78 & 80.9 \\
$\begin{array}{c}\text { pyrophosphate } \\
\text { Sodium } \\
\text { Tripolyphosphate }\end{array}$ & 4.13 & 0.77 & 81.3
\end{tabular}

These values are expressed as the average of three tests.

a) Concentration of builder, $0.05 \%$

b) Removal efficiencies were calculated in the same way as those in Table 2.

品添加物として許可されており，安全性の点で優れてい るので以下の実験に使用した。

3. ビルダー単独およびショ糖脂肪酸エステルとの組 合せによる洗浄効果

ビルダーとして, 一般に縮合リン酸塩, 有機酸塩, 有 機キレート化剤などが知られているが，その中でも特に 食品添加物に限定し, 洗浄試験を行った. Table 3 にビ ルダー単独使用の場合の洗浄効果を示す. 縮合リン酸塩 系の方が有機酸塩系の効果より優れていた. Table 4 に, ビルダーとショ糖脂肪酸エステルとの併用時の洗浄効果 について示す。この場合も, やはり, 縮合リン酸塩系の
Table 4. Influence of Combination of Sugar Laurate and Builders to Removal Effect on Residual Bordeaux $(\mathrm{Cu})$ Added to Tomato

\begin{tabular}{l|c|c|c} 
& \multicolumn{2}{|c|}{ Residues } & Removal \\
\cline { 2 - 3 } \multicolumn{1}{c|}{ Builder } & $\begin{array}{c}\text { Before } \\
\text { washing } \\
\text { (ppm) }\end{array}$ & $\begin{array}{c}\text { After } \\
\text { washing } \\
\text { (ppm) }\end{array}$ & $\begin{array}{c}\text { efficiency }{ }^{\mathrm{b}} \text { (\%) } \\
(\%)\end{array}$ \\
\hline Sodium citrate & 4.17 & 0.67 & 83.9 \\
Sodium malate & 3.58 & 0.66 & 81.6 \\
$\begin{array}{l}\text { Potassium } \\
\text { pyrophosphate }\end{array}$ & 4.13 & 0.34 & 91.8 \\
$\begin{array}{c}\text { Sodium } \\
\text { tripolyphosphate }\end{array}$ & 4.01 & 0.40 & 90.1
\end{tabular}

These values are expressed as the average of three tests.

a) Concentration of builder; $0.05 \%$; concentration of sugar laurate; $0.05 \%$

b) Removal effiencies were calculated in the same way as those in Table 2.

効果の方が有機酸塩系の効果を上回ることが認められ た.いずれもショ糖脂肪酸エステル単独あるいはビルダ 一単独の場合に比べて洗浄効果は増強された。

\section{4. 洗浄剤濃度の影響}

界面活性剂として，ショ糖ラウリン酸の代わりに発泡 性の少ないショ糖オレイン酸エステルを配合し, ビルダ 一として洗浄剤が液体のためにトリポリリン酸ナトリウ ムよりも水溶性の高いピロリン酸カリウムを採用し，リ ン酸は全体の $\mathrm{pH}$ を中性に保つために使用し, Table 5 に示す洗浄剤（これらの成分はいずれも使用基準のない

Table 5. Influence of Concentrations of Detergent $\mathrm{A}^{\text {a) }}$ to Removal Effect on Residual Bordeaux $(\mathrm{Cu})$ Added to Tomato

\begin{tabular}{|c|c|c|c|}
\hline \multirow{2}{*}{$\begin{array}{l}\text { Concentra- } \\
\text { tion of } \\
\text { detergent } \\
(\%)\end{array}$} & \multicolumn{2}{|c|}{ Residues } & \multirow{2}{*}{$\begin{array}{c}\text { Removal } \\
\text { efficiency } \\
(\%)\end{array}$} \\
\hline & $\begin{array}{c}\text { Before } \\
\text { washing } \\
\text { (ppm) }\end{array}$ & $\begin{array}{l}\text { After } \\
\text { washing } \\
\text { (ppm) }\end{array}$ & \\
\hline 0 & 4.69 & 2.04 & 56.4 \\
\hline 0.1 & 4.78 & 0.87 & 81.8 \\
\hline 0.2 & 4.51 & 0.38 & 91.6 \\
\hline 0.3 & 4.38 & 0.31 & 92.9 \\
\hline
\end{tabular}

These values are expressed as the average of three tests.

a) Composition of detergent $\mathrm{A}$

Sugar oleate $\quad 5 \%$

Potassium pyrophosphate 20\%

Orthophosphoric acid 4\%

Water 71\%

b) Removal efficiencies were calculated in the same way as those in Table 2. 
Table 6. Comparison of Detergent A and Liquid Detergent for Kitchin Use in Removal Effect on Residual Bordeaux (Cu) Added to Tomato

\begin{tabular}{|c|c|c|c|}
\hline & \multicolumn{2}{|c|}{ Residues } & \multirow{2}{*}{$\begin{array}{l}\text { Removal } \\
\text { efficiency }{ }^{\mathrm{b})} \\
(\%)\end{array}$} \\
\hline & $\begin{array}{c}\text { Before } \\
\text { washing } \\
\text { (ppm) }\end{array}$ & $\begin{array}{c}\text { After } \\
\text { washing } \\
\text { (ppm) }\end{array}$ & \\
\hline Detergent $A^{b)}$ & 4.23 & 0.34 & 92.0 \\
\hline $\begin{array}{l}\text { Liquid detergent for } \\
\text { kitchin use } \mathrm{u}^{\mathrm{c}}\end{array}$ & 4.41 & 1.39 & 68.5 \\
\hline
\end{tabular}

These values are expressed as the average of three tests.

a) Removal efficiencies were calculated in the same way as those in Table 2.

b) Concentration of detergent A, $0.2 \%$

c) Concentration of liquid detergent for kitchin use: $0.2 \%$

Table 7. Influence of Washing Times to Removal Effect of Detergent $A^{a)}$ on Residual Bordeaux $(\mathrm{Cu})$ Added to Tomato

\begin{tabular}{c|c|c|c}
\multirow{2}{*}{$\begin{array}{c}\text { Washing } \\
\text { time } \\
\text { (seconds) }\end{array}$} & $\begin{array}{c}|c| \\
\text { Before } \\
\text { washing } \\
\text { (ppm) }\end{array}$ & $\begin{array}{c}\text { After } \\
\text { washing } \\
\text { (ppm) }\end{array}$ & $\begin{array}{c}\text { Removal } \\
\text { efficiency } \\
\text { (\%) }\end{array}$ \\
\hline 30 & 4.84 & 1.54 & 68.3 \\
60 & 4.75 & 0.75 & 84.3 \\
120 & 4.96 & 0.42 & 91.5 \\
300 & 4.82 & 0.30 & 93.8
\end{tabular}

These values are expressed as the average of three tests.

a) Concentration of detergent A, $0.2 \%$

b) Removal efficiencies were calculated in the same way as those in Table 2.

食品添加物であり,なるべく安全なものを組み合わせ た. 以後, 洗浄剂 $\mathrm{A}$ と称する）を配合し，以下，標準使 用条件を検討した.

Table 5 に示すように， $0.2 \%$ 以上の使用濃度では, 効力はほとんど増加しないことが認められた。

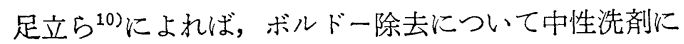
よる洗浄と水洗との間に大きな差がないことより, 中性 洗剂之洗浄剂 A の洗浄効果について比較した. Table 6 に示すように, ボルドー除去に関する限り, 洗浄剂 $\mathrm{A} の$ 方が効力的に数段上回っていることを確認した。

\section{5. 洗浄時間の影響}

洗浄剤Aを用いて，洗浄時間について検討した結果 を, Table 7 に示す. 2 分以上, 洗浄すれば, 洗浄効果 は，ほぼ横ばいとなることが認められた。
Table 8. Influence of Washing Temperatures to Removal Effect of Detergent $A^{\text {a) }}$ on Residual Bordeaux $(\mathrm{Cu})$ Added to Tomato

\begin{tabular}{|c|c|c|c|}
\hline \multirow[b]{2}{*}{$\begin{array}{l}\text { Washing } \\
\text { temp. } \\
\left({ }^{\circ} \mathrm{C}\right)\end{array}$} & \multicolumn{2}{|c|}{ Residues } & \multirow{2}{*}{$\begin{array}{c}\text { Removal } \\
\text { efficiency }{ }^{b} \\
(\%)\end{array}$} \\
\hline & $\begin{array}{c}\text { Before } \\
\text { washing } \\
\text { (ppm) }\end{array}$ & $\begin{array}{c}\text { After } \\
\text { washing } \\
\text { (ppm) }\end{array}$ & \\
\hline 15 & 4.54 & 0.63 & 86.2 \\
\hline 25 & 4.69 & 0.44 & 90.6 \\
\hline 35 & 4.82 & 0.30 & 93.8 \\
\hline 45 & 4.48 & 0.25 & 94.5 \\
\hline
\end{tabular}

These values are expressed as the average of three tests.

a) Concentration of detergent $\mathrm{A}, 0.2 \%$

b) Removal efficiencies were calculated in the same way as those in Table 2.

Table 9. Influence of Stirrings to Removal Effect of Detergent $\mathrm{A}^{\mathrm{a})}$ on Residual Bordeaux $(\mathrm{Cu})$ Added to Tomato

\begin{tabular}{|c|c|c|c|}
\hline \multirow{2}{*}{$\begin{array}{l}\text { Intensity } \\
\text { of } \\
\text { stirring } \\
\text { (r.p.m.) }\end{array}$} & \multicolumn{2}{|c|}{ Residues } & \multirow{2}{*}{$\begin{array}{c}\text { Removal } \\
\left.\text { efficiency }{ }^{\mathrm{b}}\right) \\
(\%)\end{array}$} \\
\hline & $\begin{array}{l}\text { Before } \\
\text { washing } \\
\text { (ppm) }\end{array}$ & $\begin{array}{l}\text { After } \\
\text { washing } \\
\text { (ppm) }\end{array}$ & \\
\hline 30 & 4.52 & 0.71 & 84.2 \\
\hline 50 & 4.44 & 0.38 & 91.5 \\
\hline 100 & 4.68 & 0.32 & 93.1 \\
\hline
\end{tabular}

These values are expressed as the average of three tests.

a) Concentration of detergent A, $0.2 \%$

b) Removal efficiencies were calculated in the same way as those in Table 2.

\section{6. 洗浄温度の影響}

洗浄剂 Aの洗浄温度との関係について調べた，Table 8 に示されるように, 高温洗浄の方が洗浄効果の点で有 利であるが，あまり高温で洗浄することは品質的に好ま しくないと思われるので，30〜 $35^{\circ}$ が適当と思われる.

\section{7. かくはんの影響}

Table 9 に, プロペラ羽根の回転数を変えて, 洗浄へ の影響を調べた結果を示す．かくはんが強まるほど，洗 浄効果も比例して増強されることが確認できた. しかし ながら回転数 $50 \mathrm{rpm}$ 以上になると, 効力の増強は, 緩 やかになることも認められた。

\section{8. 洗浄液 $\mathbf{p H}$ の影響}

一般にトマト洗浄液は, トマト中のクエン酸などの 溶出のため $\mathrm{pH} 4.5 \sim 5.0$ となっているほか, 酸を添加 して洗浄 ${ }^{16)}$ するケースも多く, ボルドー除去を対象と した場合に酸洗浄が効果的であるとの報告も幾つか発 
Table 10. Influence of $\mathrm{pH}$ to Removal Effect on Residual Bordeaux $(\mathrm{Cu})$ Added to Tomato by Washing

\begin{tabular}{|c|c|c|c|c|c|c|}
\hline \multirow{3}{*}{$\begin{array}{l}\text { Washing } \\
\text { proce- } \\
\text { dures }\end{array}$} & \multicolumn{3}{|c|}{ Water washing } & \multicolumn{3}{|c|}{ Detergent $A^{a)}$ washing } \\
\hline & \multicolumn{2}{|c|}{ Residues } & \multirow[b]{2}{*}{$\begin{array}{l}\text { Removal } \\
\text { efficiency } \\
(\%)\end{array}$} & \multicolumn{2}{|c|}{ Residues } & \multirow[b]{2}{*}{$\begin{array}{l}\text { Removal } \\
\text { efficiency } \\
(\%)\end{array}$} \\
\hline & $\begin{array}{c}\text { Before } \\
\text { washing } \\
\text { (ppm) }\end{array}$ & $\begin{array}{c}\text { After } \\
\text { washing } \\
\text { (ppm) }\end{array}$ & & $\begin{array}{c}\text { Before } \\
\text { washing } \\
\text { (ppm) }\end{array}$ & $\begin{array}{c}\text { After } \\
\text { washing } \\
\text { (ppm) }\end{array}$ & \\
\hline 2 & 4.33 & 0.36 & 91.8 & 4.00 & 0.28 & 93.1 \\
\hline 3 & 4.12 & 0.56 & 86.5 & 4.28 & 0.33 & 92.2 \\
\hline 4 & 4.64 & 1.52 & 67.2 & 4.50 & 0.37 & 91.9 \\
\hline 5 & 4.19 & 2.09 & 50.2 & 4.38 & 0.39 & 91.0 \\
\hline 6 & 4.67 & 2.78 & 40.4 & 4.24 & 0.40 & 90.5 \\
\hline
\end{tabular}

These values are expressed as the average of three tests.

a) Concentration of detergent A, $0.2 \%$

b) Removal efficiencies were calculated in the same way as those in Table 2.

表(8),8) 10)されていることより，中性から酸性領域まで $\mathrm{pH}$ を変化させて，洗浄剤 $\mathrm{A}$ を添加した場合と無添加の 場合の洗浄効果について比較した. Table 10 上り明らか なように, pH が低いほど，いずれも洗浄効果は高めら れる. 特に洗浄剤 $\mathrm{A}$ 無添加の場合，著しく増強されるこ とが認められた．逆にいえば，洗浄剤 Aを添加すること により $\mathrm{pH}$ の変動による洗浄効率への影響が小さくなり 安定した効果が得られるが，もし酸のみで洗浄する場合 には，絶えず，酸を連続的に添加するなぞ $\mathrm{pH}$ が上昇し ないように留意しなければならないことが，本実験結果 から分かる．ボルドーの場合，pH が低い汪ど洗浄効率 が良くなるのはトマト表面の銅が溶解されやすくなるた めと思われる.

なお本実験において使用したトマトのボルドー散布前 の銅量は, 測定の結果, いずれも $0.3 \sim 0.4 \mathrm{ppm}$ であっ た.したがって，本実験で $0.3 \sim 0.4 \mathrm{ppm}$ の銅残存量を 示したものについては，ほ㜔宣に銅は除去されている とみなすことができる.トマト中の固有銅量について, $0.1 \sim 0.6 \mathrm{ppm}$ (Hopkins, Eisen) $)^{17)}, 0.6 \sim 2.6 \mathrm{ppm}$

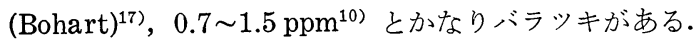
本実験で得られた $0.3 \sim 0.4 \mathrm{ppm}$ の数值は必ずしもトマ 卜固有銅量と断言できないが，洗浄剂 $\mathrm{A}$ の洗浄力からい って，ほぼ固有銅量に近いであろうことが推察できる。

\section{要 約}

洗浄によるトマト表面のボルドー除去効果について検 討し，以下の結果を得た。

1）各種の代表的界面活性剂とショ糖脂肪酸エステル のトマトに付着したボルドーの除去効果を比較したが， ほとんぞ差は見られなかった。

2）ショ糖脂肪酸エステルにビルダーを併用すること により，ボルドー除去効果を，大幅に増強できることを 確認した。ビルダーとして, 縮合リン酸塩が良好な結果
を示し，有機酸塩の効力を上回った.

3）安全性を考慮して, 界面活性剂としてショ糖脂肪 酸エステルを，ビルダーとして最も良好な結果を示した ピロリン酸カリウムを主成分とした液体洗浄剤を配合し た。このものは, 各成分が食品添加物から構成されてお り, 従来からの中性洗剂と比較した場合, ボルドー除去 に関しては，はるかに，優れた性能を有することが認め られた。

4）本洗浄剂は，濃度 $0.2 \%$ 以上，洗浄時間 2 分以上， 洗浄温度 $25^{\circ}$ 以上，かくはん $50 \mathrm{rpm}$ 以上の使用条件で は，ほぼ満足すべき結果を示した。

5）酸添加のみでトマトを洗浄した場合， $\mathrm{pH}$ の上昇 とともに，急激にボルドー除去効果が低下するために， 酸の濃度管理を厳重に行う必要があることが分かった。 これに対し, 本洗浄剂を使用した場合, 洗浄効力は $\mathrm{pH}$ の影響をあまり受けないので， $\mathrm{pH}$ の調整に留意する必 要性も少なく, 実際の使用に当たっては有利であること を確認した。

文献

1）農薬の残留基準：食衛誌．16，82（1975).

2) 川城 㦑, 岡田太郎, 辰濃 隆, 藤巻昌子: 衛生 試報. 81，78 (1963).

3）小野口邦夫：食衛誌. 4, 362 (1963).

4）小谷新太郎, 田辺弘也, 中根正行, 上田雅彦, 高 田ユリ，富山新一：食品衛生研究, 19, 781 (1969).

5) 出浦 浩：食衛誌. 13，63 (1972).

6) 末永泉二, 斎藤晴彦: 衛生化学, 11, 73 (1965).

7） 久保田源四郎：缶詰時報, 42 (10), 47 (1963).

8）飯島隆志, 青井由美：食品工誌. 12，239 (1965).

9）山沢新吾，吉崎 繁，前川孝昭，大塚秀光：同 上, 20, 54 (1973).

10）足立由郎, 鵜飼暢雄：缶詰時報, $43(9), 17(1964)$. 
11）大塚謙一, 吉沢淑, 今井四郎, 相羽浩一, 猿渡 一由：食衛誌. 3, 69 (1962).

12）上遠 章, 河田 党, 堀 正伅編集: “農薬講座 $3 ”$ p. 35 (1964) 朝倉書店.

13) Osipow, L., Snell, F.D., Marra, D.: Ind. Eng. Chem., 48, 1462 (1956).
14) Schwartz, A. M., Rader, C. A.: J. Am. Oil Chem. Soc., 42, 800 (1965).

15) Osipow, L., Snell, F.D.: ibid., 38, 184 (1961).

16）“食品技術普及シリーズ第 9 号トマト加工技術”p. 41 (1974) 農林省食品総合研究所.

17）同上, p. 15 (1974) 農林省食品総合研究所. 